SULTANIST: Jurnal Manajemen dan Keuangan

Volume: 7 No: 2 Tahun 2019 Page (73-80)

ISSN: 2338-4328 (Print), ISSN: 2686-2646 (Online)

Available online at: https://sultanist.ac.id/index.php/sultanist

\title{
DAMPAK STRUKTUR MODAL DAN STRUKTUR ASET TERHADAP NILAI PERUSAHAAN PADA PT MERCK, TbK YANG TERDAFTAR DI BURSA EFEK INDONESIA
}

\author{
Alvia Misdayana1, Yansen Siahaan ${ }^{2}$, Christine D. Nainggolan ${ }^{3}$, Sepbeariska Manurung ${ }^{4}$ \\ Program Studi Manajemen, Sekolah Tinggi Ilmu Ekonomi Sultan Agung, \\ alviamisdayana97@gmail.com \\ Program Studi Manajemen, Sekolah Tinggi Ilmu Ekonomi Sultan Agung, \\ yansensiahaan59@gmail.com, christinedewinainggolan@gmail.com, \\ sepbeariska@gmail.com,
}

\begin{abstract}
Abstrak
Berbagai cara dilakukan para manajer untuk menghadapi persaingan bisnis, salah satunya adalah dengan meningkatkan nilai perusahaan. Beberapa faktor yang mempengaruhi nilai perusahaan suatu perusahaan seperti struktur modal dan struktur aset. Tujuan penelitian ini adalah untuk mengetahui gambaran struktur modal, struktur aset dan nilai perusahaan pada PT Merck, Tbk yang terdaftar di Bursa Efek Indonesia, dan untuk mengetahui pengaruh struktur modal dan struktur aset terhadap nilai perusahaan pada ada PT Merck, Tbk yang terdaftar di Bursa Efek Indonesia baik secara simultan dan parsial. Penelitian ini digunakan dengan menggunakan analisis deskriptif kualitatif dan analisis deskriptif kuantitatif. Objek penelitian ini adalah laporan keuangan PT Merck, Tbk yang terdaftar di Bursa Efek Indonesia. Pengumpulan data dilakukan dengan metode dokumentasi. Teknik analisis yang digunakan adalah uji asumsi klasik, analisis regresi linier berganda, koefisien korelasi dan koefisien determinasi dan uji hipotesis. Hasill penelitian ini dapat disimpulkan bahwa nilai rata-rata struktur modal mengalami fluktuasi dan cenderung meningkat, nilai rata-rata struktur aset mengalami fluktuasi dan cenderung meningkat, nilai rata-rata nilai perusahaan mengalami fluktuasi dan cenderung menurun, hasil pengujian regresi linear struktur modal dan struktur aset berpengaruh negatif terhadap nilai perusahaan pada PT Merck, Tbk yang terdaftar di Bursa Efek Indonesia, hasil koefisien korelasi dan koefisien determinasi diperoleh nilai korelasi atau hubungan yang sangat kuat antara struktur modal dan struktur aset dengan nilai perusahaan, hasil uji $\mathrm{F}$ diperoleh bahwa struktur modal dan struktur aset berpengaruh signifikan terhadap nilai perusahaan, hasil uji t struktur modal dan struktur aset berpengaruh signifikan terhadap nilai perusahaan secara parsial.
\end{abstract}

Kata Kunci : Struktur Modal, Struktur Aset, Nilai Perusahaan.

\section{THE IMPACT OF CAPITAL STRUCTURE AND ASSET STRUCTURE ON THE VALUE OF THE COMPANY AT PT MERCK, TBK LISTED ON THE INDONESIA STOCK EXCHANGE}

\begin{abstract}
Various ways do managers to face business competition, one of which is to increase the value of the company. Some factors affecting the company's such as capital structure and asset structure. The purpose of this research are to describe the capital structure, asset structure and firm value, to determine the effect of the capital structure and asset structure on firm value at PT Merck, Tbk which is listed on the Indonesia Stock Exchange both simultaneously and partially. The research was conducted using qualitative descriptive analysis and quantitative descriptive analysis. The object of this research is the financial statements of PT Merck, Tbk, which is registered at Bursa Efek Indonesia. Data collection is done by the documentation method. The analysis technique used is the classic assumption test, multiple linear regression analysis, correlation coefficient and coefficient of determination and hypothesis testing. The results of this research can be concluded as the average value of the Capital Structure fluctuates and tends to increase, the average value of the Asset Structure fluctuates and tends to increase, the average value of the Firm Value fluctuates and tends to decrease, the results of testing linear regression of capital structure and asset structure have a negative effect on firm value at PT Merck, Tbk, which is listed on the Indonesia Stock Exchange, the results of the correlation coefficient and coefficient of determination obtained a correlation value or a very strong relationship between capital structure and asset structure with firm value, the results of the F test show that the capital structure and asset structure have a significant effect on firm value, the results of the t test of the capital structure and asset structure have a significant effect on firm value.
\end{abstract}

Keywords: Capital Structure, Asset Structure, Firm Value 


\section{PENDAHULUAN}

Perkembangan perekonomian dunia yang semakin maju menyebabkan persaingan bisnis semakin ketat, sehingga perusahaan harus mampu bersaing untuk dapat tumbuh menjadi perusahaan yang lebih baik. Persaingan tersebut mendorong para manajer perusahaan untuk berusaha lebih keras dalam mempertahankan posisi dan mengembangkan kemajuan perusahaan. Manifestasi keberhasilan perusahaan dapat dilihat dari perkembangan minat investor untuk menjadi mitra perusahaan. Berbagai cara dilakukan para manajer untuk menghadapi persaingan tersebut, salah satunya adalah dengan meningkatkan nilai perusahaan. Nilai perusahaan adalah tingkat keberhasilan perusahaan yang menjadi persepsi investor yang sering dikaitkan dengan harga saham. Indikator yang digunakan untuk mengukur nilai perusahaan adalah Earning per Share (EPS). Earning per Share (EPS) adalah komponen penting pertama yang harus diperhatikan dalam analisis perusahaan.

Beberapa faktor yang mempengaruhi nilai perusahaan suatu perusahaan seperti struktur modal dan struktur aset. Struktur modal merupakan suatu struktur yang menggambarkan hutang jangka pendek, hutang jangka panjang dan modal sendiri dalam suatu perusahaan. Indikator yang digunakan untuk mengukur struktur modal dalam penelitian ini adalah Long-term Debt to Equity Ratio. Struktur aset merupakan rasio yang digunakan untuk mengukur seberapa besar aset tetap perusahaan dibanding dengan total aset perusahaan. Indikator yang digunakan dalam struktur aset adalah Fixed Assets Ratio.

Berikut ini disajikan gambaran struktur modal yang diukur dengan Long-term Ddebt to Equity Ratio(LtDER), Struktur aset diukur dengan Fixed Assets ratio (FAR) dan Nilai perusahaan diukur dengan Earning Per Share (EPS) pada PT Merck, Tbk yang terdaftar di Bursa Efek Indonesia periode 2010 - 2017 dapat dilihat pada Tabel 1 dibawah ini.

Tabel 1. Gambaran Struktur Modal, Struktur Aset dan Nilai Perusahaan pada PT Merck, Tbk periode 2010-2017

\begin{tabular}{|c|c|c|c|}
\hline \multirow{2}{*}{ Tahun } & $\begin{array}{c}\text { Struktur } \\
\text { Modal }\end{array}$ & $\begin{array}{c}\text { Struktur } \\
\text { Aset }\end{array}$ & $\begin{array}{c}\text { Nilai } \\
\text { Perusahaan }\end{array}$ \\
\cline { 2 - 4 } & $\begin{array}{r}\text { LtDER } \\
\text { (kali) }\end{array}$ & $\begin{array}{c}\text { FAR } \\
\text { (kali) }\end{array}$ & $\begin{array}{c}\text { EPS } \\
\text { (Rp) }\end{array}$ \\
\hline 2010 & 0,053 & 0,247 & $5.303,32$ \\
\hline 2011 & 0,050 & 0,159 & $10.319,58$ \\
\hline 2012 & 0,079 & 0,185 & $4.812,86$ \\
\hline 2013 & 0,072 & 0,156 & $7.832,36$ \\
\hline 2014 & 0,060 & 0,169 & $8.101,44$ \\
\hline 2015 & 0,075 & 0,246 & $2.463,34$ \\
\hline 2016 & 0,070 & 0,316 & 343,40 \\
\hline 2017 & 0,076 & 0,327 & 322,94 \\
\hline $\begin{array}{c}\text { Rata- } \\
\text { rata }\end{array}$ & $\mathbf{0 , 0 6 7}$ & $\mathbf{0 , 2 2 6}$ & $\mathbf{4 . 9 3 7 , 4 0}$ \\
\hline
\end{tabular}

Sumber: Laporan Keuangan PT Merck, Tbk yang terdaftar di Bursa Efek Indonesia (Data diolah, 2019)

Berdasarkan tabel 1 di atas, dapat dilihat bahwa nilai Struktur Modal (LtDER), Struktur Aset (FAR) mengalami fluktuasi dan cenderung meningkat, sedangkan Nilai Perusahaan (EPS) mengalami fluktuasi dan cenderung menurun. Tujuan dalam penelitian ini adalah untuk mengetahui gambaran struktur modal, struktur aset dan nilai perusahaan pada PT Merck, Tbk yang terdaftar di Bursa Efek Indonesia, dan untuk mengetahui pengaruh struktur modal dan struktur aset terhadap nilai perusahaan pada PT Merck, Tbk yang terdaftar di Bursa Efek Indonesia baik secara simultan maupun parsial.

\section{LANDASAN TEORI}

\section{Struktur Modal}

Menurut Hermuningsih menyatakan struktur modal yang optimal oleh perusahaan ditunjukkan dari struktur modal yang dapat memaksimalkan harga saham, target struktur modal yang optimal 
nilainya dapat berubah-ubah sesuai dengan keputusan manajemen perusahaan. Menurut Najmudin (2011), faktor-faktor yang mempengaruhi struktur modal adalah Risiko bisnis, Fleksibilitas finansial, Tarif pajak, Sikap manajemen, Stabilitas penjualan, Struktur asset, Profitabilitas, Ukuran perusahaan.

\section{Struktur Aset}

Menurut Riyanto (2009), beberapa faktor yang mempengaruhi besar kecilnya piutang melalui investasi yang juga berpengaruh terhadap total aset adalah Tingkat Penjualan Kredit, Syarat Pembayaran Penjualan Kredit, Kebijakan Pengumpulan piutang, Tipe Pelanggan, Usaha Penagihan. Struktur aktiva menggambarkan besarnya aktiva yang dapat dijaminkan perusahaan ketika perusahaan melakukan pinjaman kepada kreditor. Struktur aktiva merupakan proporsi aktiva tetap yang dimiliki perusahaan (Mawikere dan Rate, 2015).

\section{Nilai Perusahaan}

Menurut Monika dan M (2014), nilai perusahaan adalah nilai pasar karena nilai perusahaan memberikan kemakmuran pemegang saham ecara maksimum apabila harga saham meningkat. Semakin tinggi harga saham, maka semakin tinggi kemakmuran pemegang saham. Tujuan perusahaan adalah untuk memaksimumkan nilai perusahaan, oleh karena itu dalam pengambilan keputusan perusahaan harus selalu mempertimbangkan akibatnya terhadap nilai perusahaan atau harga saham. Terdapat banyak faktor yang mempengaruhi nilai perusahaan, namun faktor yang utama adalah faktor pendanaan perusahaan (Febrianti, 2012).

\section{METODE}

Penelitian ini menggunakan data sekunder dengan membaca dan mencari informasi melalui alat elektronik (browsing) dan mempelajari buku-buku karangan ilmiah, catatan, referensi lainnya yang berhubungan dengan bahan penelitian. Desain penelitian ini adalah penelitian kepustakaan (library research). Teknik analisis data yang digunakan adalah analisis deskriptif kualitatif dan analisis deskriptif kuantitatif.

\section{HASIL DAN PEMBAHASAN \\ Analisis Deskriptif Kualitatif}

\section{Analisis Struktur Modal PT Merck, Tbk yang terdaftar di Bursa Efek Indonesia Periode 2010-2017}

Berikut ini disajikan gambaran struktur modal yang diukur dengan LtDER (Longterm Debt to Equity Ratio) pada PT Merck, Tbk yang terdaftar di Bursa Efek Indonesia periode 2010 sampai dengan 2017 pada tabel 2 berikut:

Tabel 2. Rata-rata Struktur Modal pada PT Merck, Tbk yang terdaftar di Bursa

Efek Indonesia Periode 2010-2017

\begin{tabular}{|c|c|}
\hline Tahun & $\begin{array}{c}\text { LtDER } \\
\text { (kali) }\end{array}$ \\
\hline 2010 & 0,053 \\
\hline 2011 & 0,050 \\
\hline 2012 & 0,079 \\
\hline 2013 & 0,072 \\
\hline 2014 & 0,060 \\
\hline 2015 & 0,075 \\
\hline 2016 & 0,070 \\
\hline 2017 & 0,076 \\
\hline Nilai LtDER Minimum (kali) & $\mathbf{0 , 0 5 0}$ \\
\hline Nilai LtDER Maksimum (kali) & $\mathbf{0 , 0 7 9}$ \\
\hline Rata-rata Per Tahun (kali) & $\mathbf{0 , 0 6 7}$ \\
\hline
\end{tabular}

Sumber: Laporan Keuangan PT Merck, Tbk (Data diolah, 2019)

Berdasarkan tabel 2 di atas, bahwa keadaan struktur modal yang diproksikan dengan LtDER (Long-term Debt to Equity Ratio) mengalami fluktuasi cenderung meningkat. Hal ini disebabkan oleh peningkatan hutang jangka panjang meningkat lebih tinggi daripada peningkatan total ekuitas. Nilai rata-rata 
LtDER (Long-term Debt to Equity Ratio) pada PT Merck, Tbk yang terdaftar di Bursa Efek Indonesia periode 2010-2017 sebesar 0,067 kali. Artinya setiap Rp 1 modal sendiri akan dijadikan jaminan hutang jangka panjang sebesar Rp 0,067

Analisis Struktur Aset PT Merck, Tbk yang terdaftar di Bursa Efek Indonesia Periode 2010-2017

Berikut ini disajikan gambaran struktur aset yang diukur dengan Fixed Assets Ratio (FAR) pada PT Merck, Tbk yang terdaftar di Bursa Efek Indonesia periode 2010 sampai dengan 2017 pada tabel 3 berikut:

Tabel 3. Rata-rata Struktur Aset pada PT Merck, Tbk yang terdaftar di

Bursa Efek Indonesia Periode 2010-2017

\begin{tabular}{|c|c|}
\hline Tahun & FAR (kali) \\
\hline 2010 & 0,247 \\
\hline 2011 & 0,159 \\
\hline 2012 & 0,185 \\
\hline 2013 & 0,156 \\
\hline 2014 & 0,169 \\
\hline 2015 & 0,246 \\
\hline 2016 & 0,316 \\
\hline 2017 & 0,327 \\
\hline $\begin{array}{c}\text { Nilai LtDER } \\
\text { Minimum (kali) }\end{array}$ & $\mathbf{0 , 1 5 6}$ \\
\hline $\begin{array}{c}\text { Nilai LtDER } \\
\text { Maksimum (kali) }\end{array}$ & $\mathbf{0 , 3 2 7}$ \\
\hline $\begin{array}{c}\text { Rata-rata Per } \\
\text { Tahun (kali) }\end{array}$ & $\mathbf{0 , 2 2 6}$ \\
\hline
\end{tabular}

Sumber: Laporan Keuangan PT Merck, Tbk (Data diolah, 2019)

Berdasarkan tabel 3 di atas, bahwa keadaan struktur aset yang diukur dengan Fixed Assets Ratio (FAR) cenderung meningkat. Hal ini disebabkan aset tetap meningkat lebih tinggi daripada peningkatan total aset. Nilai rata-rata Fixed Assets Ratio (FAR) pada PT Merck, Tbk yang terdaftar di Bursa Efek Indonesia periode 2010-2017 sebesar 0,225 kali. Artinya aset tetap sebesar 0,226 kali dari total aset.

Analisis Nilai Perusahaan PT Merck, Tbk yang terdaftar di Bursa Efek Indonesia Periode 2010-2017
Berikut ini disajikan gambaran nilai perusahaan yang diukur dengan Earning Per Share (EPS) pada PT Merck, Tbk yang terdaftar di Bursa Efek Indonesia periode 2010 sampai dengan 2017 pada tabel 4 berikut:

Tabel 4. Rata-rata Nilai Perusahaan pada PT Merck, Tbk yang terdaftar di Bursa Efek Indonesia Periode 2010-2017

\begin{tabular}{|c|r|}
\hline Tahun & EPS (Rp) \\
\hline 2010 & $5.303,32$ \\
\hline 2011 & $10.319,58$ \\
\hline 2012 & $4.812,86$ \\
\hline 2013 & $7.832,36$ \\
\hline 2014 & $8.101,44$ \\
\hline 2015 & $2.463,34$ \\
\hline 2016 & 343,40 \\
\hline 2017 & 322,94 \\
\hline $\begin{array}{c}\text { Nilai LtDER } \\
\text { Minimum (kali) }\end{array}$ \\
\hline $\begin{array}{c}\text { Nilai LtDER } \\
\text { Maksimum (kali) }\end{array}$ \\
\hline $\begin{array}{c}\text { Rata-rata Per Tahun } \\
\text { (kali) }\end{array}$ & $\mathbf{1 0 . 3 1 9 , 5 8}$ \\
\hline
\end{tabular}

Sumber: Laporan Keuangan PT Merck, Tbk (Data diolah, 2019)

Berdasarkan tabel 3.3 di atas, bahwa keadaan nilai perusahaan yang diukur dengan Earning Per Share (EPS) cenderung menurun. Hal ini disebabkan menurunnya laba bersih sesudah pajak dan meningkatnya jumlah saham beredar karena adanya stock split. Nilai rata-rata Earning Per Share (EPS) pada PT Merck, Tbk yang terdaftar di Bursa Efek Indonesia periode 2010-2017 sebesar Rp 4.937,40. Artinya keuntungan untuk setiap lembar saham yang diterima investor adalah sebesar Rp 4.937,40.

\section{Analisis Deskriptif Kuantitatif}

\section{Analisis Regresi Linear Berganda}

Analisis regresi digunakan untuk mengetahui pengaruh antara struktur modal dan struktur aset terhadap nilai perusahaan. Untuk mengetahui ini maka menggunakan analisis regresi linear berganda dapat dilihat pada tabel 5 berikut ini: 
Tabel 5. Hasil Analisis Regresi

Linier Berganda Coefficients $^{a}$

\begin{tabular}{|cc|r|r|c|}
\hline \multirow{2}{*}{} & \multicolumn{2}{|c|}{$\begin{array}{c}\text { Unstandardized } \\
\text { Coefficients }\end{array}$} & $\begin{array}{c}\text { Standardized } \\
\text { Coefficients }\end{array}$ \\
\cline { 2 - 5 } & \multicolumn{1}{|c|}{ B } & Std. Error & Beta \\
\hline & (Constant) & 22932,505 & 1508,336 & \\
1 & LtDER & - & 22996,925 &,- 369 \\
& FAR & 123376,889 & &,- 806 \\
\hline
\end{tabular}

a. Dependent Variable: EPS

Sumber: Hasil Pengolahan Data (2019)

Berdasarkan hasil analisis regresi linear berganda di atas, maka diperoleh model persamaan regresi sebagai berikut:

\section{$\hat{\mathbf{Y}}=\mathbf{2 2 9 3 2 , 5 0 5}-\mathbf{1 2 3 3 7 6 , 8 8 9} \mathrm{X}_{1-}$ 43187,903X $\mathrm{X}_{2}$}

Dari hasil persamaan regresi berganda di atas, dapat disimpulkan bahwa struktur modal dan struktur aset berpengaruh negatif terhadap nilai perusahaan pada PT Merck, Tbk yang terdaftar di Bursa Efek Indonesia periode 2010-2017.

\section{Analisis Koefisien Korelasi dan Koefisien Determinasi}

Koefisien korelasi digunakan untuk melihat korelasi antara nilai perusahaan (Y) dengan struktur modal $\left(\mathrm{X}_{1}\right)$ dan struktur aset $\left(\mathrm{X}_{2}\right)$. Angka koefisien pada selang $0<\mathrm{r}<1$ atau $-1<\mathrm{r}<0$. Adapun hasil pengolahan data yang menunjukkan koefisien korelasi dapat dilihat pada Tabel 6 berikut ini:

Tabel 6. Hasil Analisis Koefisien dan Koefisien Determinasi Model Summary ${ }^{b}$

\begin{tabular}{|l|c|r|r|c|}
\hline Model & $\mathrm{R}$ & $\begin{array}{c}\mathrm{R} \\
\text { Square }\end{array}$ & $\begin{array}{c}\text { Adjusted } \\
\text { R Square }\end{array}$ & $\begin{array}{c}\text { Std. Error } \\
\text { of the } \\
\text { Estimate }\end{array}$ \\
\hline 1 &, $989^{\mathrm{a}}$ &, 979 &, 970 & 636,614331 \\
\hline
\end{tabular}

a. Predictors: (Constant), FAR, LtDER

b. Dependent Variable: EPS

Sumber: Hasil Pengolahan Data (2019)

Berdasarkan Tabel 6 diperoleh hasil $\mathrm{r}$ sebesar 0,989. Sesuai dengan kriteria pada Tabel 3.4 dapat disimpulkan bahwa terdapat korelasi atau hubungan yang sangat kuat antara struktur modal dan struktur aset dengan nilai perusahaan pada PT Merck, Tbk yang terdaftar di Bursa Efek Indonesia periode 2010-2017. Nilai R Square adalah sebesar 0,979. Koefisien tersebut menyatakan bahwa struktur modal dan struktur aset dapat menjelaskan nilai perusahaan sebesar $97,9 \%$ sedangkan $2,1 \%$ dijelaskan oleh variabel lain atau faktor lain yang tidak dimasukkan dalam model regresi ini seperti: keputusan investasi dan manajemen aset.

\section{Uji Hipotesis}

\section{Uji Simultan (Uji F)}

Uji F ini dilakukan secara simultan untuk mengetahui apakah struktur modal dan strukturaset berpengaruh terhadap nilai perusahaan secara simultan. Adapun hasil uji $\mathrm{F}$ dalam penelitian ini dapat di lihat pada Tabel 7 berikut ini:

Tabel 7. Hasil Uji F hitung

\begin{tabular}{|c|c|c|c|c|c|}
\hline \multicolumn{6}{|c|}{$A N O V A^{a}$} \\
\hline Model & $\begin{array}{l}\text { Sum of } \\
\text { Squares }\end{array}$ & $\begin{array}{l}\mathrm{d} \\
\mathrm{f}\end{array}$ & $\begin{array}{l}\text { Mean } \\
\text { Square }\end{array}$ & $\mathrm{F}$ & Sig. \\
\hline $\begin{array}{l}\text { Regressi } \\
\text { on }\end{array}$ & $\begin{array}{r}94001872,6 \\
75\end{array}$ & 2 & $\begin{array}{r}47000936,3 \\
37\end{array}$ & $\begin{array}{r}115,9 \\
72\end{array}$ & $\begin{array}{r}, 00 \\
0^{\mathrm{b}}\end{array}$ \\
\hline 1. Residul & 2026389,03 & 5 & 405277,807 & & \\
\hline Total & $\begin{array}{r}96028261,7 \\
09\end{array}$ & 7 & & & \\
\hline
\end{tabular}

a. Dependent Variable: EPS

b. Predictors: (Constant), FAR, LtDER

Sumber: Hasil Pengolahan Data (2019)

Berdasarkan tabel 7 di atas dapat dilihat bahwa nilai $F_{\text {hitung }}$ sebesar 115,972 dan $F_{\text {tabel }}$ sebesar 5,79 menunjukkan bahwa $F_{\text {hitung }}>$ $F_{\text {tabel }}$ yaitu 115,972> 5,79 dengan tingkat signifikan $0,000<0,050$, maka dapat disimpulkan bahwa $\mathrm{H}_{0}$ ditolak artinya struktur modal dan struktur aset berpengaruh signifikan terhadap nilai perusahaan pada PT Merck, Tbk yang terdaftar di Bursa Efek Indonesia periode 2010-2017. 


\section{Uji Parsial (Uji t)}

Uji t ini dilakukan untuk mengetahui pengaruh dari struktur modal dan struktur aset terhadap nilai perusahaan. Adapun hasil uji t dalam penelitian ini dapat dilihat pada Tabel 8 berikut ini:

Tabel 8

Hasil Uji thitung

\begin{tabular}{|c|c|c|}
\hline Model & $\mathrm{T}$ & Sig. \\
\hline $\begin{array}{ll} & \text { (Constant) } \\
1 & \text { LtDER } \\
& \text { FAR }\end{array}$ & $\begin{array}{r}15,204 \\
-5,365 \\
-11,735\end{array}$ & $\begin{array}{l}, 000 \\
, 003 \\
, 000\end{array}$ \\
\hline
\end{tabular}

a. Dependent Variable: EPS

Berdasarkan tabel 8 di atas, dapat diketahui bahwa Long-term Debt to Equity Ratio (LtDER) sebagai parameter struktur modal mempunyai nilai thitung sebesar 5,365 sedangkan nilai $t_{\text {tabel }}$ dengan $\mathrm{df}=\mathrm{n}-\mathrm{k}-1$ (8-21) sebesar 2,57058. Dengan demikian, dapat disimpulkan bahwa $t_{\text {hitung }}>t_{\text {tabel }}$ atau 5,365 > 2,57058 dengan taraf signifikansi 0,004 < 0,05 maka dapat dikatakan bahwa $\mathrm{H}_{0}$ ditolak, artinya struktur modal berpengaruh negatif dan signifikan terhadap nilai perusahaan pada PT Merck, Tbk yang terdaftar di Bursa Efek Indonesia tahun 2010-2017. Fixed Assets Ratio (FAR) sebagai parameter struktur aset mempunyai nilai $t_{\text {hitung }}$ sebesar 11,735 sedangkan nilai $t_{\text {tabel }}$ dengan $\mathrm{df}=\mathrm{n}-\mathrm{k}-1$ (8-2-1) sebesar 2,57058. Dengan demikian, dapat disimpulkan bahwa $t_{\text {hitung }}>\mathrm{t}_{\text {tabel }}$ atau 11,735 $>$ 2,57058 dengan taraf signifikansi $0,000<$ 0,05 maka dapat dikatakan bahwa $\mathrm{H}_{0}$ ditolak, artinya struktur aset berpengaruh negatif dan signifikan terhadap nilai perusahaan pada PT Merck, Tbk yang terdaftar di Bursa Efek Indonesia tahun 2010-2017.

\section{Evaluasi}

Evaluasi Struktur Modal pada PT Merck Indonesia Tbk yang terdaftar di Bursa Efek Indonesia Periode 2010-2017
Dari hasil penelitian ini, menunjukkan hasil analisis struktur modal dengan menggunakan Long-term Debt to Equity Ratio(LtDER) pad PT Merck, Tbk yang terdaftar di Bursa Efek Indonesia periode 2010-2017 berfluktuasi cenderung meningkat. Hal ini disebabkan oleh peningkatan hutang jangka panjang seperti hutang imbalan kerja dan hutang jangka panjang lainnya dan total ekuitas seperti saldo laba yang cenderung meningkat.

Evaluasi Struktur Aset pada PT Merck, Tbk yang terdaftar di Bursa Efek Indonesia Periode 2010-2017

Dari hasil analisis menunjukkan bahwa struktur aset mengalami fluktuasi dan cenderung meningkat. Hal ini disebabkan meningkatnya aset tetap seperti aset pajak tangguhan, aset tak berwujud dan properti investasi lainnya dan total aset seperti aset tetap yang cenderung meningkat.

Evaluasi Nilai Perusahaan pada PT Merck, Tbk yang terdaftar di Bursa Efek Indonesia Periode 2010-2017

Dari hasil analisis menunjukkan bahwa nilai perusahaan mengalami penurunan yang drastis. Hal ini disebabkan karena adanya stock split yang menyebabkan jumlah saham beredar meningkat secara signifikan.

\section{Evaluasi Pengaruh Struktur Modal terhadap Nilai Perusahaan pada PT Merck, Tbk yang terdaftar di Bursa Efek Indonesia Periode 2010-2017 \\ Berdasarkan hasil analisis regresi linier berganda yang telah dilakukan, diketahui struktur modal berpengaruh negatif terhadap nilai perusahaan pada PT Merck, Tbk periode 2010-2017. Terlihat dari persamaan regresi linier berganda, yaitu $\hat{\mathbf{Y}}=\mathbf{2 2 9 3 2 , 5 0 5}$ - 123376,889X $X_{1}-43187,903 X_{2}$}


Evaluasi Pengaruh Struktur Aset terhadap Nilai Perusahaan pada PT Merck, Tbk yang terdaftar di Bursa Efek Indonesia Periode 2010-2017

Dari persamaan regresi linier berganda yang telah dilakukan, dapat disimpulkan bahwa struktur aset berpangaruh negatif terhadap nilai perusahaan pada PT Merck, Tbk periode 2010-2017. Terlihat dari persamaan regresi linier berganda, yaitu $\hat{\mathbf{Y}}=$ 22.932,505 - 123.376,889 $\mathrm{X}_{1}-43.187,903 \mathrm{X}_{2}$

Evaluasi Pengaruh Struktur Modal dan Struktur Aset terhadap Nilai Perusahaan pada PT Merck, Tbk yang terdaftar di Bursa Efek Indonesia Periode 2010-2017.

Berdasarkan hasil analisis regresi linier berganda yang telah dilakukan, diketahui bahwa struktur modal dan struktur aset berpengaruh negatif terhadap nilai perusahaan pada PT Merck, Tbk periode 2010-2017. Terlihat dari persamaan regresi linier berganda, yaitu $\hat{\mathbf{Y}}=\mathbf{2 2 . 9 3 2 , 5 0 5}$ 123.376,889 $\mathrm{X}_{1}-43.187,903 \mathrm{X}_{2}$

\section{SIMPULAN DAN SARAN}

\section{Kesimpulan}

Nilai rata-rata struktur modal yang dihasilkan oleh PT Merck, Tbk yang terdaftar di Bursa Efek Indonesia periode 2010-2017 mengalami fluktuasi dan cenderung meningkat. Nilai struktur modal yang memiliki nilai di atas rata-rata berada pada tahun 2012, 2013, 2014, 2015, 2016 dan 2017 dan nilai struktur modal yang memiliki nilai dibawah rata-rata berada pada tahun 2010 dan 2011.

Nilai rata-rata struktur aset yang dihasilkan oleh PT Merck, Tbk yang terdaftar di Bursa Efek Indonesia periode 2010-2017 mengalami fluktuasi dan cenderung meningkat. Nilai struktur aset yang memiliki nilai di atas rata-rata berada pada tahun 2010, 2015, 2016 dan 2017 dan nilai struktur aset yang memiliki nilai dibawah rata-rata berada pada tahun 2011, 2012, 2013 dan 2014.

Nilai rata-rata nilai perusahaan yang dihasilkan oleh PT Merck, Tbk yang terdaftar di Bursa Efek Indonesia periode 2010-2017 mengalami fluktuasi namun cenderung menurun. Nilai perusahaan yang memiliki nilai di atas rata-rata berada pada tahun 2010, 2011, 2013, dan 2014 dan nilai perusahaan yang memiliki nilai dibawah rata-rata berada pada tahun 2012, 2015, 2016 dan 2017.

Berdasarkan hasil pengujian regresi linear berganda yaitu struktur modal dan struktur aset berpengaruh negatif terhadap nilai perusahaan pada PT Merck, Tbk yang terdaftar di Bursa Efek Indonesia periode 2010-2017. Hasil koefisien korelasi dan koefisien determinasi diperoleh nilai korelasi atau hubungan yang sangat kuat antara struktur modal dan struktur aset dengan nilai perusahaan. Sementara untuk hasil determinasi diketahui bahwa struktur modal (LtDER) dan struktur aset (FAR) berpengaruh $97,9 \%$ terhadap nilai perusahaan, sedangkan sisanya $2,1 \%$ dipengaruhi oleh faktor lain yang tidak diteliti dalam penelitian ini seperti keputusan investasi dan manajemen aset.

Dari hasil uji $F$ diperoleh bahwa struktur modal dan struktur aset berpengaruh signifikan terhadap nilai perusahaan pada PT Merck, Tbk yang terdaftar di Bursa Efek Indonesia periode 2010-2017. Hasil uji t struktur modal dan struktur aset berpengaruh negatif dan signifikan terhadap nilai perusahaan pada PT Merck, Tbk yang terdaftar di Bursa Efek Indonesia tahun 2010-2017 secara parsial.

\section{Saran}

Untuk meningkatkan produktivitas sebaiknya perusahaan mengendalikan hutang jangka panjang yang dimilikinya, 
karena produktivitas akan meningkatkan penjualan sehingga laba juga dapat meningkat. Untuk meningkatkan total aset sebaiknya perusahaan dapat meningkatkan produktivitas, mempercepat perputaran piutang dan sebagainya, sehingga perusahaan tetap menghasilkan laba yang cenderung meningkat. Sebaiknya perusahaan juga meningkatkan laba bersih sesudah pajak dan mempertahankan jumlah saham beredar dan tidak melakukan pemecahan nilai saham karena dengan adanya pemecahan saham maka laba per saham berkurang.

\section{DAFTAR PUSTAKA}

Febrianti, M. (2012). Faktor-faktor yang mempengaruhi nilai perusahaan pada industri pertanbangan di Bursa Efek Indonesia. Jurnal Bisnis Dan Akuntansi, 14(2), 141-156.

Hermuningsih, S. 2012. Pengaruh profitabilitas, size terhadap Nilai perusahaan dengan struktur modal sebagai variabel Intervening. Jurnal Siasat Bisnis, 16 (2), 232-242.

Mawikere, C.Y., dan Rate, P. (2015). Pengaruh stabilitas penjualan dan struktur aktiva terhadap struktur modal perusahaan automotive and allied product yang terdaftar di BEI Periode 2010-2013. EMBA, 3(3), 149-159.

Monika, R. T., dan M. (2014). Pengaruh kinerja keuangan terhadap nilai perusahaan pada perusahaan manufaktur yang terdaftar di Bursa Efek Indonesia. Jurnal manajemen Dan Bisnis Sriwijaya, 12, 1-16.

Najmudin. (2011). Manajemen Keuangan dan Akuntansi Syar'iyyah Modern. Yogyakarta: Andi Offset.
Riyanto, Bambang. (2009). Dasar-Dasar Pembelajaran Perusahaan. Yogyakarta: BPFE Yogyakarta.

\section{PROFIL SINGKAT}

Alvia Misdayana, Pematangsiantar, 06 Nopember 1997, Pendidikan terakhir Sarjana Akuntansi dari STIE Sultan Agung, 2019. Yansen Siahaan, lahir di Pematangsiantar pada tanggal 15 Nopember tahun 1955. Menyelesaikan pendidikan Doktor pada Program Studi Ilmu Akuntansi di Universitas Sumatera Utara pada tahun 2018. Saat ini beliau menjabat sebagai Ketua Program Studi Sarjana Akuntansi di STIE Sultan Agung. Christine Dewi Nainggolan, Pematangsiantar, 11 Desember 1986 Pendidikan terakhir Pascasarjana Program Studi Akuntansi dari Universitas Sumatera Utara, 2017 dan sekarang bekerja sebagai Dosen Tetap bidang Akuntansi STIE Sultan Agung. Sepbeariska Manurung, Pematangsiantar, 26 September 1986 Pendidikan terakhir Pascasarjana Program Studi Akuntansi dari Universitas Sumatera Utara dan sekarang bekerja sebagai Dosen Tetap bidang Akuntansi STIE Sultan Agung 